Aim of the study: To find differences between a group of patients with intraocular melanoma and another primary cancer and a group of patients with no identifiable second primary cancer.

Material and methods: The analysis involved 240 participants, selected from patients who were treated for uveal melanoma at the Department of Ophthalmology and Ocular Oncology of the Jagiellonian University Medical College between the year 1998 and 2007. Among those patients 97 were diagnosed with one or more independent primary cancers. Those patients were subject to a comparative analysis with a second group of 143 patients who had uveal melanoma with no identifiable second primary cancer. Results: Statistically significant differences between the group of patients with intraocular melanoma and an other primary cancer, and the group of patients with uveal melanoma (but without another diagnosed primary neoplasm) were as follows: more common family history of cancer, better education, living in cities (especially with a population over 500 thousand), previous surgery except for uveal melanoma, and two or less than two pregnancies in the case of women.

Conclusions: This analysis revealed that more common family history of cancer, better education, living in cities (especially with a population over 500 thousand), previous surgery, except for uveal melanoma, and two or less than two pregnancies in the case of women, were associated with a higher rate of detection of multiple primary cancers.

Key words: uveal melanoma, multiple primary cancers.

Contemp Oncol (Pozn) 2013; 17 (6): 510-514 DOI: $10.5114 /$ wo.2013.38914

\section{The impact of selected factors on early diagnosis of multiple primary cancers in patients with uveal melanoma}

\author{
Marzena Mierzwa-Dobranowska, Bożena Romanowska-Dixon
}

Department of Ophthalmology, Clinic of Ophthalmology and Ocular Oncology, Jagiellonian University, Medical College, Kraków, Poland

\section{Introduction}

Uveal melanoma is the most common primary intraocular cancer in adults [1]. The tumor occurs in approximately 4.3-7 cases per million per year [2-5] and comprises $2.9 \%$ of all melanomas [4].

Anomalies in chromosomes 1, 3, 6, 8, 13, 16, 18 in uveal melanoma have been described $[6,7]$. The most common prognosis-affecting chromosomal disorders associated with the tumor include: loss of chromosome 1p, 3, 6q and $8 p$ and an extra copy of chromosome $6 p$ and $8 q$ [6-9]. According to many authors monosomy 3 is associated with highly aggressive, rapidly progressive disease [7, 10-14].

There are some other reported cases of primary cancers in patients with uveal melanoma, but limited data exist regarding factors causing development of another primary cancers among the affected patients.

There are reports on development of other primary cancers of other organs available in the literature [15-17].

The problem of multiple primary cancers emerged as a medical issue already in the nineteenth century. Renaud in 1847 and Rokitansky in 1855 reported cases of two independent cancers [15].

The aim of the current analysis was to find differences between the group of patients with intraocular melanoma and another malignant neoplasm of different origin, and another group of patients with uveal melanoma but no other diagnosed primary cancer. Primary malignancies included skin cancers, colon cancer, skin melanoma, cancers involving the breast and genital tract in females and other less common cancers in our analysis.

\section{Material and methods}

Two hundred forty patients diagnosed and treated with uveal melanoma at the Clinic of Ophthalmology and Ocular Oncology of the Jagiellonian University Medical College in Kraków, Poland, from January 1998 to December 2007 were included in the analysis. The study group involved 97 patients with other primary malignancies; 57 (58.8\%) patients were females and 40 (41.2\%) were males. The patients' age ranged between 35 and 83, with a mean age of $63.2 \pm 9.9$ (Table 1 ).

Information about patients' current health condition and answers to questionnaires were obtained from 87 patients ( 51 women and 36 men) or their relatives. In other cases, data were analyzed on the basis of the medical history. The above-mentioned group was compared with another group of patients with uveal melanoma but without the diagnosis of another primary cancer. The control group consisted of 143 patients, 83 (58\%) females and $60(42 \%)$ males, aged 36-87 years, with a mean age of $59.6 \pm 12.1$ (Table 2).

The analysis was based on the clinical examination and data were obtained from patients (or their relatives) during a follow-up. 
An analysis of the influence of factors including marital status, education, occupation, place and region of residence, smoking, alcohol consumption, exposure to sunlight, exposure to harmful chemicals, hormonal factors and a history of pregnancy, a history of surgery for treatment of unbound uveal melanoma and the presence of cancer in the family (on the occurrence of multiple primary cancers in patients with uveal melanoma) was performed.

Statistical analysis was performed using the $\chi^{2}$ test, logistic regression and Kaplan-Meier survival curves. Statistical significance was accepted as $p<0.05$.

\section{Results}

Patients with multiple primary cancers, compared to patients without the diagnosis of other primary malignancies, reported more commonly a family history of cancer in $1^{\text {st }}$ degree relatives $(p=0.0073)$ and in $1^{\text {st }}$ and/or $2^{\text {nd }}$ degree relatives ( $p=0.0001)$ (Figs. 1, 2).

Patients with multiple primary malignancies more often had secondary and higher education $(p=0.0001)$, more often worked [according to the ISCO-88 (COM) classification] as "professionals" ( $p=0.0001)$ [18], were primarily city dwellers [as opposed to living in rural areas $(p=0.0060)$ ], especially cities with a population over 500 thousand ( $p=$ $=0.0001$ ) [19], more frequently had a history of surgery unrelated to uveal melanoma $(p=0.0000)$, and - in the case of women - had fewer $(\leq 2)$ pregnancies on average ( $p=0.0008)$ (Figs. 3 [18], 4, 5 [19], 6, 7).

Logistic regression analysis revealed that the prevalence of multiple primary cancers in patients with uveal melanoma depended on a few above-mentioned factors: secondary and higher education, living in a city with a population of over 500 thousand, undergoing surgery, and a family history of cancer (in $1^{\text {st }}$ and $1^{\text {st }}$ and/or $2^{\text {nd }}$ degree relatives). Patients' profession was not taken into consideration in logistic regression analysis, because this variable was dependent on the education. The number of pregnancies was not taken into consideration as well, because of its limitation to women (Table 3,4 ).

The occurrence of other primary cancers among patients with uveal melanoma was not statistically signifi-

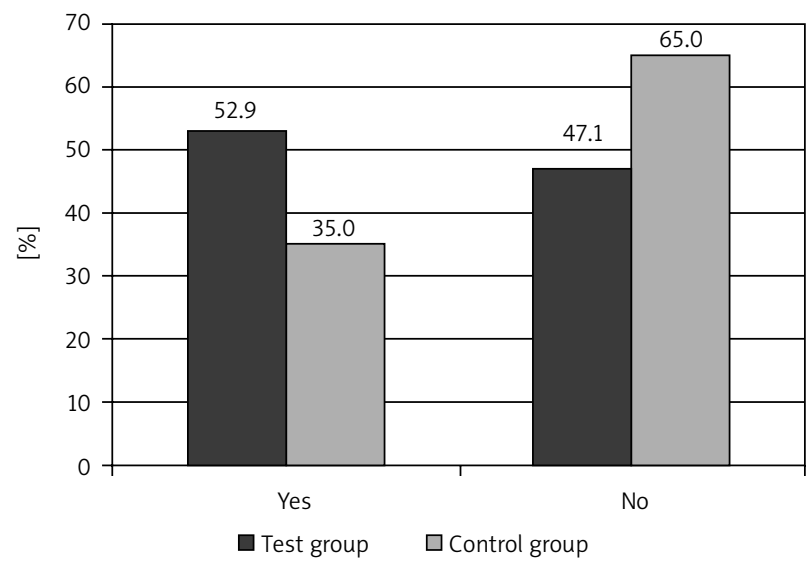

$p=0.0073$

Fig. 1. Appearance of multiple primary cancers, depending on the occurrence of cancer among first degree relatives of patients
Table 1 . Characteristics of the study group

\begin{tabular}{|cccc|}
\hline Gender & $\begin{array}{c}\text { Number of } \\
\text { patients }\end{array}$ & Mean age & $\begin{array}{c}\text { Standard } \\
\text { deviation }\end{array}$ \\
women & $57(58.8 \%)$ & 61.6 & 9.8 \\
men & $40(41.2 \%)$ & 65.0 & 9.9 \\
Total & 97 & 63.2 & 9.9 \\
\hline
\end{tabular}

Table 2. Characteristics of the control group

\begin{tabular}{|lccc|}
\hline Gender & $\begin{array}{c}\text { Number of } \\
\text { patients }\end{array}$ & Mean age & $\begin{array}{c}\text { Standard } \\
\text { deviation }\end{array}$ \\
\hline women & $83(58.0 \%)$ & 59.3 & 11.8 \\
\hline men & $60(42.0 \%)$ & 60.0 & 12.6 \\
\hline Total & 143 & 59.6 & 12.1 \\
\hline
\end{tabular}

cantly associated with other individually analyzed factors listed above.

\section{Discussion}

Patients with multiple primary cancers, compared to patients without the diagnosis of other primary malignancies, reported more common family history of cancers among their relatives.

Abdel-Rahman et al. [20] observed that uveal melanoma patients with a family history suggesting a high risk of predisposition to a known cancer syndrome were at significantly higher risk for having a second cancer, compared to the remaining uveal melanoma patients.

Bergman et al. [21] observed an increased risk of second primary cancers among Swedish patients with uveal melanoma but Callejo et al. [22] reported that in their Canadian cohort the statistical analysis showed no increased risk of a second cancer in patients with uveal melanoma.

That analysis showed that those patients' educational level had a significant effect on the diagnosis and the presence of multiple primary cancers. Those who had

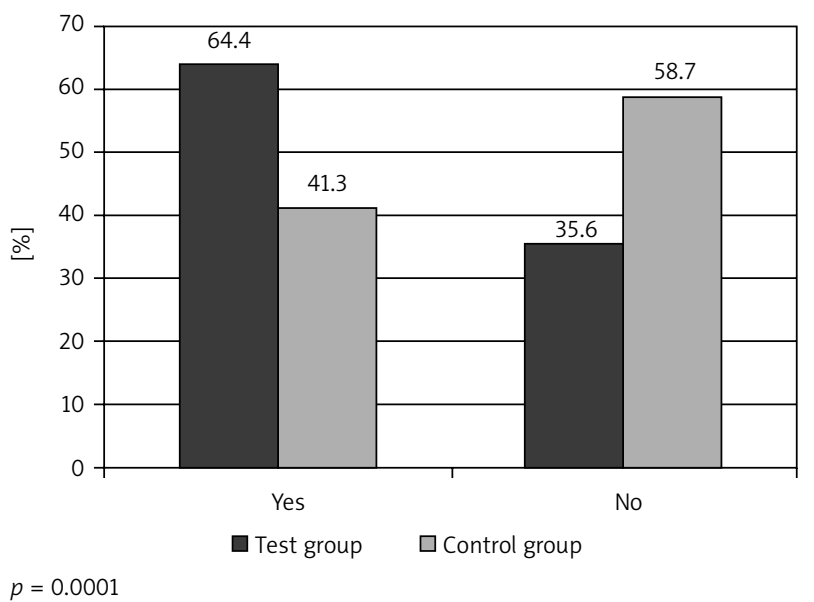

Fig. 2. Appearance of multiple primary cancers, depending on the occurrence of cancer among those patients' first and/or second degree relatives 


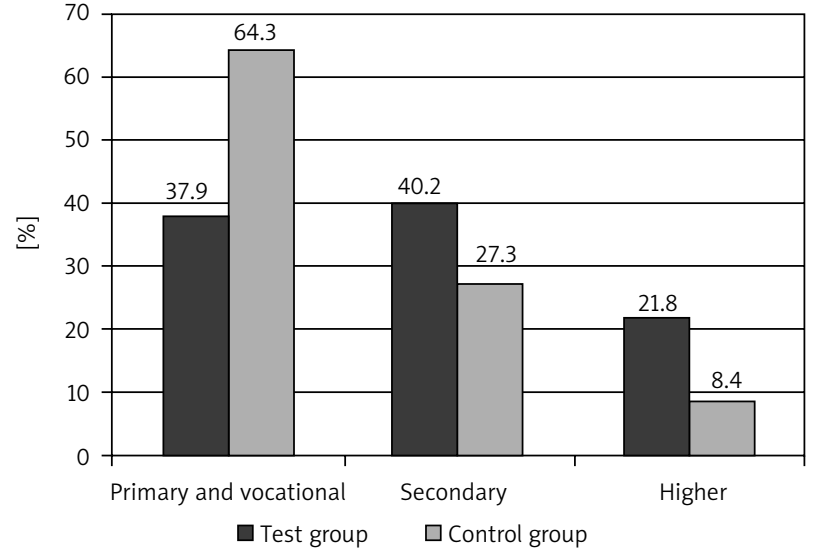

$p=0.0001[18]$

Fig. 3. Appearance of multiple primary cancers, depending on the level of education of patients

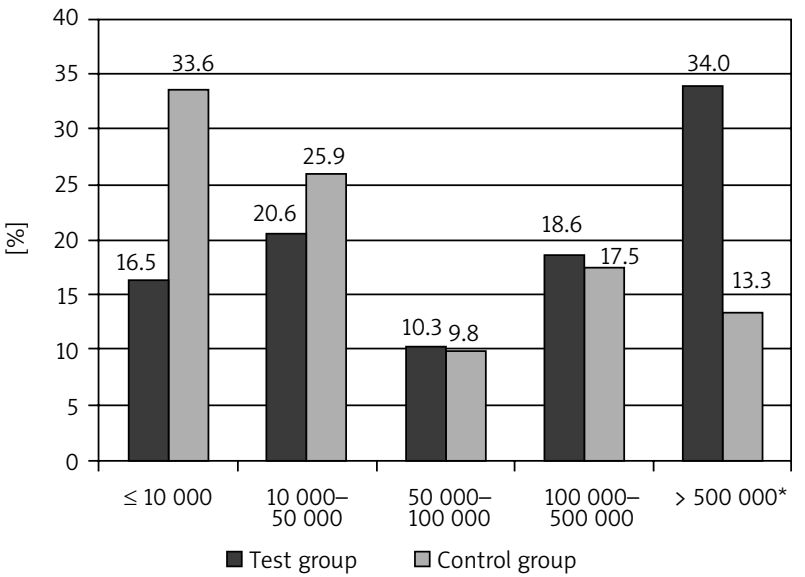

${ }^{*} p=0.0001[19]$

Fig. 5. Appearance of multiple primary cancers, depending on the place of residence, considering the population volume

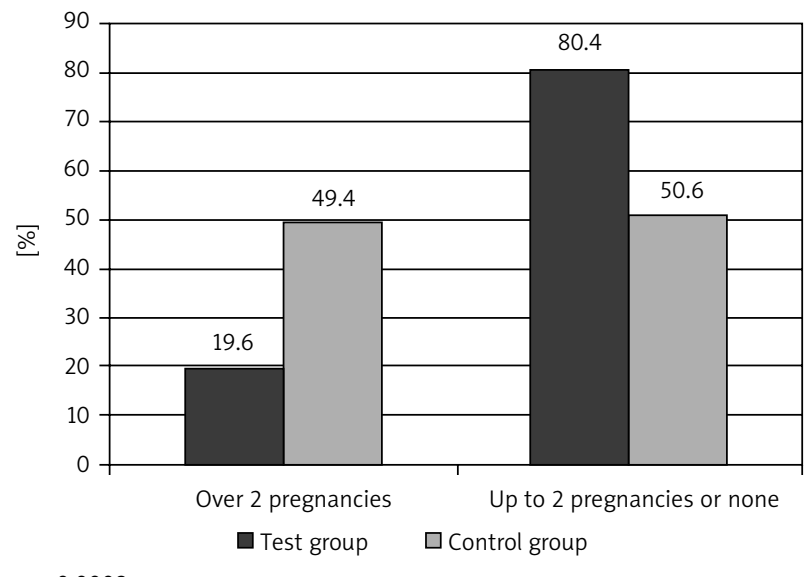

$p=0.0008$

Fig. 7. Appearance of multiple primary cancers, depending on the number of pregnancies

higher education were represented in a greater number in the group of patients diagnosed with a second primary cancer. In that group, a significantly higher number of patients were classified (according to the ISCO-88 (COM) classification) as "professionals". The result indicates how

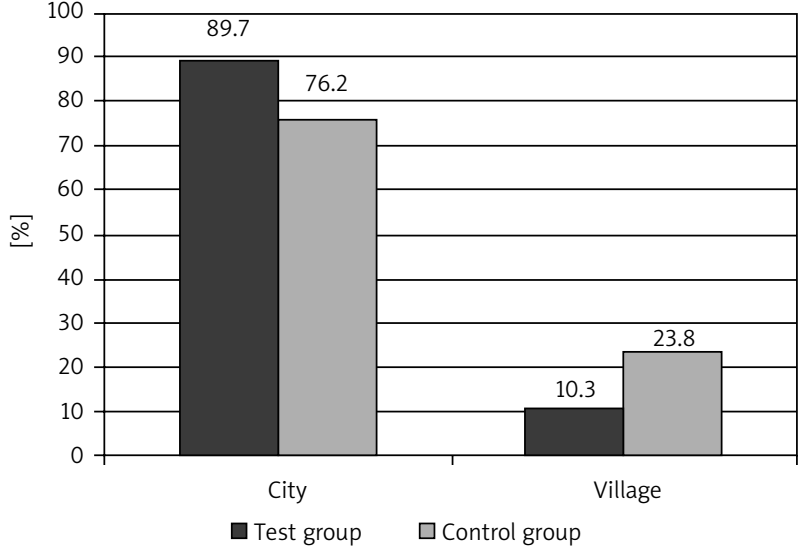

$p=0.0060[19]$

Fig. 4. Appearance of multiple primary cancers, depending on patients' place of living

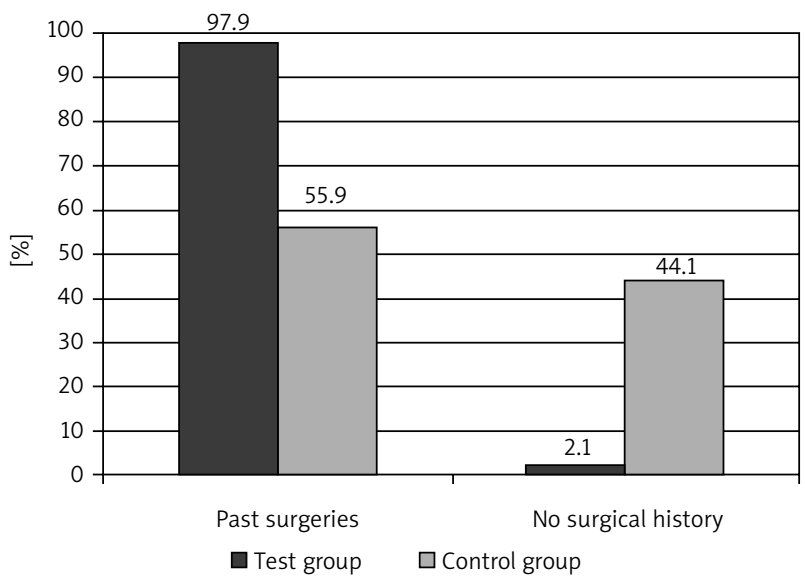

$p=0.0000$

Fig. 6. Appearance of multiple primary cancers, according to past surgery

important the individual's life and health history is when medical care based upon symptoms that may or may not suggest the presence of a cancer is sought. According to Tobiasz-Adamczyk, patients who have some disturbing signs suspect that grave illness because they have a prior knowledge of the telltale symptoms. Some patients, however, in spite of their knowledge of symptoms of cancer, may be incapable of proper diagnosis and evaluation of their condition. They may ignore or disregard the meaning of symptoms [23, 24].

Our analysis demonstrated that in the group of multiple primary cancers participants were mostly residents of large cities, usually with a population of over 500 thousand. That observation is probably associated with the influence of several factors. According to Tobiasz-Adamczyk, patients are more likely to seek medical attention when help is at hand [25]. Thus, easier access to medical institutions, services and state-of-art equipment and medical specialists may explain better detection of cancer among urban dwellers.

Availability of medical services is extremely important for patients who have uveal melanoma, because they have to be closely monitored for metastases. According to Eske- 
Table 3. Results of logistic regression

\begin{tabular}{lccccc} 
& Constant & Age & $\begin{array}{c}\text { Higher or } \\
\text { secondary } \\
\text { education }\end{array}$ & $\begin{array}{c}\text { Number of } \\
\text { inhabitants over } \\
500 \text { thousand }\end{array}$ & $\begin{array}{c}\text { Number of } \\
\text { surgeries } \\
\text { Cancers among } \mathbf{1}^{\text {st }} \\
\text { degree relatives }\end{array}$ \\
$\begin{array}{l}\text { Assessment of the } \\
\text { variable parameter }\end{array}$ & -6.434 & 0.026 & 1.171 & 1.384 & 3.840 \\
$\begin{array}{l}\text { Significance level of the } \\
\text { parameter }-p\end{array}$ & 0.000 & 0.097 & 0.000 & 0.004 & 0.000 \\
$\begin{array}{l}\text { Odds ratio (unit) } \\
-95 \% \mathrm{Cl}\end{array}$ & 1.026 & 3.226 & 3.991 & 46.539 \\
$+95 \% \mathrm{Cl}$ & 0.995 & 1.617 & 1.558 & 0.087 \\
\hline
\end{tabular}

Table 4. Results of logistic regression.

\begin{tabular}{|c|c|c|c|c|c|c|}
\hline & Constant & Age & $\begin{array}{l}\text { Higher or } \\
\text { secondary } \\
\text { education }\end{array}$ & $\begin{array}{c}\text { Number of } \\
\text { inhabitants over } \\
500 \text { thousand }\end{array}$ & $\begin{array}{l}\text { Number of } \\
\text { surgeries }\end{array}$ & $\begin{array}{c}\text { Cancers among } \\
1^{\text {st }} / 2^{\text {nd }} \text { degree } \\
\text { relatives }\end{array}$ \\
\hline $\begin{array}{l}\text { Assessment of the } \\
\text { variable parameter }\end{array}$ & -6.717 & 0.030 & 1.133 & 1.342 & 3.762 & 0.716 \\
\hline $\begin{array}{l}\text { Significance level of the } \\
\text { parameter }-p\end{array}$ & 0.000 & 0.058 & 0.001 & 0.006 & 0.000 & 0.039 \\
\hline Odds ratio (unit) & & 1.030 & 3.104 & 3.827 & 43.017 & 2.047 \\
\hline$-95 \% \mathrm{Cl}$ & & 0.999 & 1.544 & 1.479 & 9.089 & 1.038 \\
\hline$+95 \% \mathrm{Cl}$ & & 1.063 & 6.199 & 9.902 & 203.595 & 4.035 \\
\hline
\end{tabular}

lin et al., detecting metastases of uveal melanoma in patients (who have not reported any symptoms yet) may vary in the case of testing using abdominal ultrasound and assessment of liver function (from the level of 59\% for annual testing to over $95 \%$ in the case of semiannual testing [26]).

As for pregnancy, according to a literature review, hormonal changes significantly affect transformation of a choroidal naevus into a choroidal melanoma. In the group of 3,706 patients examined by Shields et al. [27], pregnant women accounted for $0.4 \%$ of respondents ( 16 people). The authors observed that only in seven of those pregnant women did tumors that were previously considered to be stable start to proliferate. Based on that observation, it was suggested that perhaps immune tolerance to the fetus promotes a greater propensity for tumor development and a non-pregnant state may preclude exacerbation of the disease.

Romanowska-Dixon suggested that pregnancy appears to constitute a risk factor for the worsening of a pre-existing aberrancy [28].

In the analyzed material none of the 140 included women having a diagnosis of uveal melanoma were pregnant. The period between the last pregnancy and the time of being treated in the Cracow Clinic ranged from 9 to 52 years in the group with multiple primary cancers, and from 3 to 57 years in the second group, with no identifiable primary cancer. Holly et al. [29], on the basis of their observations, found a correlation between decreased risk of uveal melanoma and increased parity.

Hartge et al. [30] observed an increased risk of uveal melanoma among women who had been pregnant or had previously had estrogen hormone replacement therapy. The risk decreased after surgical removal of the ovaries.
Among the patients analyzed, women with multiple primary cancers had significantly fewer pregnancies than patients who were not diagnosed with a second primary malignancy. That probably suggests a protective effect of pregnancy on the development of multiple cancers.

The described analysis was a retrospective chart review, not a prospective trial with clearly more rigorous reporting and data monitoring.

\section{Conclusions}

More common occurrence of malignant cancers in $1^{\text {st }}$ and $1^{\text {st }}$ and/or $2^{\text {nd }}$ degree relatives of patients with uveal melanoma and other primary malignancies suggests existence of a common genetic factor in the development of different cancers.

A higher occurrence rate of multiple primary cancers among patients with better education and among patients working as "professionals" emphasizes the importance of knowledge of risk factors for development of a cancer, and of resulting more scrupulous observation of the primary neoplasm and more successful initiation of prophylactic interventions.

Persons living in cities (population $>500 \mathrm{~K}$ ) are at higher risk for multiple primary cancers compared to those who live in rural areas. More frequent recognition of multiple primary cancers among persons living in cities (population > $500 \mathrm{~K}$ ) may be associated with easier access to diagnosis, treatment, practitioners and equipment and with higher awareness of the role of pollution in the development of malignant cancer.

Fewer pregnancies in the past among women with multiple primary cancers, compared to women without 
a second diagnosed primary malignancy, may suggest the protective effect of pregnancy against the development of multiple primary cancers.

The authors declare no conflict of interests.

\section{References}

1. Starzycka M. Diagnostyka i zasady leczenia czerniaków wewnątrz gałkowych. Okulistyka 2000; 1: 3-7.

2. Häusler T, Stang A, Anastassiou G, Jöckel KH, Mrzyk S, Horsthemke B, Lohmann DR, Zeschnigk M. Loss of heterozygosity of $1 p$ in uveal melanomas with monosomy 3. Int J Cancer 2005; 116: 909-13.

3. Basic and Clinical Science Course. Guzy melanocytarne. W: Patologia narzadu wzroku i guzy wewnątrzgałkowe. Wydawnictwo Medyczne Urban \& Partner, Wrocław 2005; 223-55.

4. Singh AD, Topham A. Incidence of uveal melanoma in the United States: 1973-1997. Ophthalmology 2003; 110: 956-61.

5. Shields CL, Shields JA. Ocular melanoma: relatively rare but requiring respect. Clin Dermatol 2009; 27: 122-33.

6. Kilic E, van Gils W, Lodder E, et al. Clinical and cytogenetic analyses in uveal melanoma. Invest Ophthalmol Vis Sci 2006; 47: 3703-7.

7. Aalto Y, Eriksson L, Seregard S, Larsson O, Knuutila S. Concomitant loss of chromosome 3 and whole arm losses and gains of chromosome 1, 6,or 8 in metastasizing primary uveal melanoma. Invest Ophthalmol Vis Sci 2001; 42: 313-7.

8. Tschentscher F, Prescher G, Zeschnigk M, Horsthemke B, Lohmann DR. Identification of chromosomes 3, 6, and 8 aberrations in uveal melanoma by microsatellite analysis in comparison to comparative genomic hybridization. Cancer Genet Cytogenet 2000; 122: 13-7.

9. Hughes S, Damato BE, Giddings I, Hiscott PS, Humphreys J, Houlston RS. Microarray comparative genomic hybridisation analysis of intraocular uveal melanomas identifies distinctive imbalances associated with loss of chromosome 3. Br J Cancer 2005; 93: 1191-6.

10. Thomas S, Pütter C, Weber S, Bornfeld N, Lohmann DR, Zeschnigk M. Prognostic significance of chromosome 3 alterations determined by microsatellite analysis in uveal melanoma: a long-term follow-up study. Br J Cancer 2012; 106: 1171-6.

11. Abdel-Rahman MH, Cebulla CM, Verma V, Christopher BN, Carson WE 3rd, Olencki T, Davidorf FH. Monosomy 3 status of uveal melanoma metastases is associated with rapidly progressive tumors and short survival. Exp Eye Res 2012; 100: 26-31.

12. Shields CL, Ganguly A, Bianciotto CG, Turaka K, Tavallali A, Shields JA. Prognosis of uveal melanoma in 500 cases using genetic testing of fine-needle aspiration biopsy specimens. Ophthalmology 2011; 118: 396-401.

13. Damato B, Duke C, Coupland SE, Hiscott P, Smith PA, Campbell I, Douglas A, Howard P. Cytogenetics of uveal melanoma: a 7-year clinical experience. Ophthalmology 2007; 114: 1925-31.

14. Sandinha MT, Farquharson MA, McKay IC, Roberts F. Monosomy 3 predicts death but not time until death in choroidal melanoma. Invest Ophthalmol Vis Sci 2005; 46: 3497-501.

15. Giefing M, Wierzbicka M, Szyfter K. Drugie pierwotne nowotwory głowy i szyi - przegląd teorii wyjaśniających ich powstawanie oraz najnowszej terminologii. Contemp Oncol (Pozn) 2004; 8: 466-74.

16. Zielińska-Kaźmierska B, Neskoromna A. Mnogi pierwotny nowotwór błony śluzowej jamy ustnej - opis przypadku. Contemp Oncol (Pozn) 2004; 8: 360-2.

17. Pawlęga J, Geleta M, Dyba T, Rachtan J. Drugie pierwotne nowotwory złośliwe u chorych leczonych radykalnie z powodu raka jamy ustnej, krtani i płuca. Otolaryng Pol 1994; 48: 239-45.

18. Mierzwa-Dobranowska M, Romanowska-Dixon B. Assessment of the influence of one's education on early diagnosis of multiple primary cancer in patients with uveal melanoma. Klin Oczna 2012; 114: 111-4.

19. Mierzwa-Dobranowska M, Romanowska-Dixon B. One's location of residence as an important factor related to the occurrence of multiple primary cancer among patients with uveal melanoma. Klin Oczna 2012; 114: 107-10.
20. Abdel-Rahman MH, Pilarski R, Ezzat S, Sexton J, Davidorf FH. Cancer family history characterization in an unselected cohort of 121 patients with uveal melanoma. Fam Cancer 2010; 9: 431-8.

21. Bergman L, Nilsson B, Ragnarsson-Olding B, Seregard S. Uveal melanoma: a study on incidence of additional cancers in the Swedish population. Invest Ophthalmol Vis Sci 2006; 47: 72-7.

22. Callejo SA, Al-Khalifa S, Ozdal PC, Edelstein C, Burnier MN Jr. The risk of other primary cancer in patients with uveal melanoma: a retrospective cohort study of a Canadian population. Can J Ophthalmol 2004; 39: 397-402.

23. Tobiasz-Adamczyk B, Szafraniec K, Bajka J. Postrzeganie i ocena objawów chorobowych, uwarunkowania demograficzno-społeczne. W: Zachowania w chorobie. Opis przebiegu choroby z perspektywy pacjenta. Collegium Medicum UJ, Kraków 1999; 20-30.

24. Tobiasz-Adamczyk B. Poziom wiedzy medycznej ludności jako element zachowań w zdrowiu i chorobie. W: Wybrane elementy socjologii zdrowia i choroby. Wydawnictwo Uniwersytetu Jagiellońskiego, Kraków 2000; 87-95.

25. Tobiasz-Adamczyk B, Szafraniec K, Bajka J. Definicje zachowań w chorobie. W: Zachowania w chorobie. Opis przebiegu choroby z perspektywy pacjenta. Collegium Medicum UJ, Kraków 1999; 8-19.

26. Eskelin S, Pyrhönen S, Summanen P, Prause JU, Kivelä T. Screening for metastatic malignant melanoma of the uvea revisited. Cancer 1999; 85: 1151-9.

27. Shields CL, Shields JA, Eagle RC Jr, De Potter P, Menduke H. Uveal melanoma and pregnancy. A report of 16 cases. Ophthalmology 1991; 98: 1667-73.

28. Romanowska-Dixon B. Czerniak naczyniówki u ciężarnych - obserwacje 8 przypadków. Klin Oczna 2002; 104: 395-7.

29. Holly EA, Aston DA, Ahn DK, Kristiansen JJ, Char DH. Uveal melanoma, hormonal and reproductive factors in women. Cancer Res 1991; 51: 1370-2.

30. Hartge P, Tucker MA, Shields JA, Augsburger J, Hoover RN, Fraumeni JF Jr. Case-control study of female hormones and eye melanoma. Cancer Res 1989; 49: 4622-5.

\section{Address for correspondence}

Marzena Mierzwa-Dobranowska MD, PhD

Department of Ophthalmology

Clinic of Ophthalmology and Ocular Oncology

Jagiellonian University Medical College

Kopernika 38

31-501 Krakow, Poland

e-mail: mm_m@wp.pl

Submitted: 13.08 .2012

Accepted: $\quad 7.08 .2013$ 